\title{
Ferritin の家兔腸管運動に及代す影響に就て
}

\author{
日本医科大学栄漛学教室（主任 島田解夫教授） \\ 는 \\ 鴻、熹 \\ Kōhō Go
}

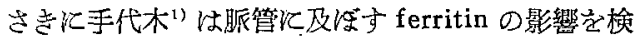
へ微星 ferritin の静脈内投与は白ネズミの血管透過 性を明が公進することを報告したが，その際偶々腹 壁を通して腸管運動が盛儿になり所謂霞動運動が不安 状態を呈するのを認めた。

Ferritinは Shorr, Mazur 等”江よると出血性 shock 時に流血中現われる V.D.M. と同一物質でめり， ferritin の静注によつて犬に忌㲾が起るこど), drum shock" ${ }^{2}$, ileus shock の場合飞も V.D.M. が流血中K 出現すること，文最近村田部が ileus shock 時にこれ を確認した等の事実梳 ferritin の作用と shock 症状 起因との間仙密接な因果関係加あることを示す。しか しながらこの方面の研究は思いの外微々たるるので殊 飞 ferritin を使用して shock の症状の個々飞就て央 験的解析を試みたものは Mazur の之层上の関係及び

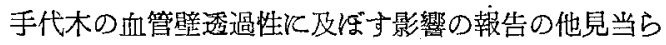
ない。ここで shock syndrome の一つである腸管運 動の異変と ferritin との関係を家鬼晹管により研究 しいさ」か見るべき結果が得られたのでここに報告す る次第である。

\section{実 臨 篇}

\section{A) 実験方法}

1) 実験動物 : $2 \mathrm{~kg}$ 前後の 雄性家鬼を一般実駼管 理法潐じ一週間以上飼育した後使用した。実験前 24 時間は饑餓とした。

2）晹管運動描写法：晹管運動描写法には従来種々 の装置が考案されているが，これを大別すれば摘出保 生晹管に上るるのと非摘出腸管を使用する方法とがあ る。実騃目的により適当選択すべきであるが，著者 の場合は主と乙て生活環境下の腸管に及ぼす ferritin の影響を観察する认あつたので当然後者に属する実験 法を選び且種々の方法汇就き追試検討を加えたが， その或るるのは腸管運動の描写力が不鋭敏であり，或 るものは検体の条件保持が容易でない等技術上の困難 を伴うことのあるのを知つた。文特に直接腸管膜血管 に楽郕定注入しとの作用を観察しようとした為従来の
方法では到底目的に添い得なかつた。そこで描写法を 種々考案試作した結果次㳅へる様な方法を組立て た。この方法往来のすのに較べて種々の利点があり 且掂用籍囲名広いるのである。いささかその組立法及 び実技を述べると次の通りである（第1図）。

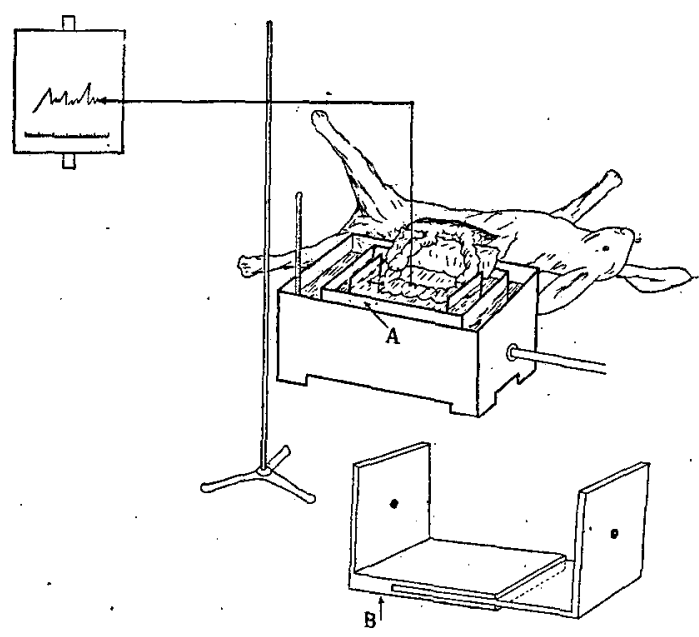

第 1 図

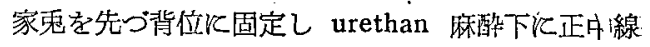

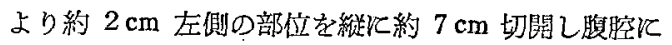
達する。虫垂を捕捉し乞の上部約 $20 \mathrm{~cm}$ の長さの空腸 を腹腔外飞静汃取出し $38^{\circ} \mathrm{C}$ 飞保つた Ringer 液内 に入れる。実験仙供する部分は約 $8 \mathrm{~cm}$ であるが，そ

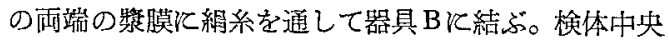
部を極細絹系(一号)反て柽く㢣垂してこれを桿杆の一 端結ぶ。次で描写飞適当の位置飞装置を動かす。この 際器具 Bはその幅が自由に謂節出来るので移動して腸

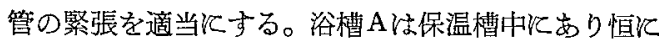
$37^{\circ} \sim 38^{\circ} \mathrm{C}$ を保つ様になつている。検体部以外の露出 部分を温湿ガーゼで难うことや浴槽栘行する部分が 住曲しない様に注意すること沟論である。梌体の部 分或いはとの近くに粪塊を認める場合には腸管の運動 が昂つて薬剤の效果判定が困難となるから極力避ける

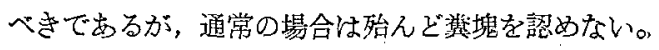


この方法は腸管運彭が極めて鋭徽に描写出来目つ腸間 膜動脈に検体を動かす学なく薬剂を注入することが

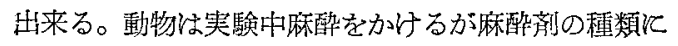
より腸管運動に異なつた影響を及ぼすからとの選択に 充分考慮を払う必要がある。著者はその影響が最も少 いと言われる urethan 学使用し类験 30 分前に 0.7 $\mathrm{g} / \mathrm{kg}$ の割合任皮下注射した。非麻醉動物を使用与る のが最る好ましいのであるが実験中体の動摇や中枢 性の影響が現われるので僅かであるが描写曲線が不安 定化する。奏験用 ferritin 馬の腷藏より Granick の法を中島6)が政良したもので䛴製し，家鬼 ferritin 洞じく島7)の2 回 incubate 法で調製した。

因にこの実験では効果出現後 20〜30 分間の変化を 追つたるので，その後のるは特別の場合を除き触れ ていない。

\section{B）実験 成 績}

1) Urethan 麻醮家鬼の腸管運動について

第 2 図 a.b.c. は著者の方法によつて得られた麻醉 :家危の腸管運動描写図である。描写操作完了後大凡 15 分間は腸管運動は停止するか或いは極めて 微弱で あるが、その後一定の Rhythmus を持つ活潑な運動が 挌こる。実験は総てこの期間に行つた。検体によつて 多少振幅の大さ及び tonus の強さ異るが琵々得られ る曲線は図の a.b.である。図中或一定の周期をるつ て増加する振幅の増大は呼吸飞伴うるのと考光られ る。この曲線恃約 70〜80 分間に亘り一定の経過をと る。

実跧負荷後の振幅の变化, tonus の消長は総て好理 前の曲線に較べて論し個体間の相違ではない。因に本 描写法の感受性てみる為に副交感神経 興倠刘である wagostigmine $0.1 \mathrm{mg} / \mathrm{kg}$ の割に皮下注射すると数 分後飞振幅の增大と tonus の增加加起る（第 3 図）。 この事は本法が相当鋭敏偒管運動の変化を描写出来 ることを物語るものである。

2) Urethan 麻醉家鬼馬 ferritin を静派内投与 しとの際起る腸管運動の変化就て

a) Ferritin $50 \mathrm{r} / \mathrm{kg}$ 投与の成績 (第 4 四)

馬 ferritin 溶液を N 含量として $50 \mathrm{r} / \mathrm{kg}$ の割合に 耳静脈から亟めて徐々に注入したが第 4 図の様に殆ん ぞ腸管運動以変化を招かない。

b) Ferritin $100 \mathrm{r} / \mathrm{kg}$ の投与成績（第 5 図）

$50 \mathrm{r} / \mathrm{kg} の$ ferritin で変化を認めなからたが，更 飞 $100 \mathrm{r} / \mathrm{kg}$; の割合飞増加し投与すると第 5 図の様に 投与直後腸管の tonus は急激に上昗し同時に振幅名著 明増加する。tonus は投与後 2 分で最高に達し, 次 で緩かな曲線を描きながら娍少し 30 分前後で正学に るどる。

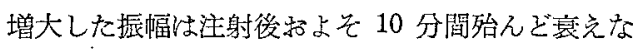
いか，去の後次第に減弱し約 30 分で旧愎吉る。 Tonus 特よび振幅の増大は前述の通り奏験動物の感 受性によつて相違するが，この失駼例では振幅の六進 度を ferritin 投与前と較べると最大では招よと它 4 5 掊に達する。曲線の型および経過に佃价差はない。

c) Ferritin $1000 \mathrm{r} / \mathrm{kg}$ の投与成績（第6 図）

Tonus 招上び振幅の卉進增大は $100 \mathrm{r} / \mathrm{kg} の$ 堨合に 輘べて急激に起り，特に振幅仿於て著しい。100 r/kg の例では和よて 30 分で圆復するのに本例では 45 分 前後になつて初めて正常化した。Tonus の復元時閒も

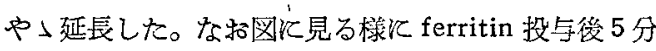
前後で一過性に振幅の減少する時期があるが，tonus の低下を伴わない事から ferritin の効果が極点侄し 腸管の痙縮を起した為と思われる。

3) Urethan 麻酔家鬼の腸間膜動脈に馬 ferritin を直接投与した場合の成績

a) 標本腸管の分布動脈に ferritin $2.5 \mathrm{r} / \mathrm{kg}$ の割 合に投与した場合

腸管運動は対照の Ringer 液の昜合とあまり变らな w。

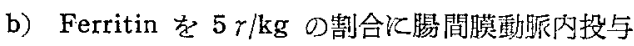
の場合（第 7 図）

投与後一過性の tonus の低下と振幅の娍衰が起る

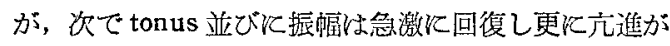
認められる。この場合掁幅の増大よりもむしる tonus の古進の方が著明である。12〜15 分間の短時間内に 低下減少し，20〜30 分前後で再び萑少な一逼性の振 幅の増化を起したのち正常に復する。

c) Ferritin $50 \% / \mathrm{kg}$ の割合渴間膜動脈内投与成 續(第 8 図)

Ferritin 投与と同時仁一且 tonus 和よで振幅は低 下消失するが，直ら回復し更に元進が起る。約 10 分 間亘つて図の様な曲線を描くがその後々洛着いた庁 進状態で経過して行く。この際最初の 10 分閻の tonus の急増には振幅の増大を伴わないがここれは tonus の 增加が余り飞急なため，振幅の変化を描写するのに不 適当になつたるのか，又は晹管が症縮を起したためか

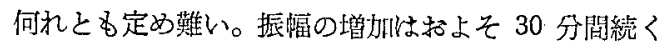
が, tonus の元進は 60〜70 分間仗及ぶ。この tonus と振幅が相伴つて正常化しないのは前記の静脈注射の 
成續己異なる点である。

4) Urethan 麻酔家兔の筋纳内K ferritin を投与 した奏験

a) Ferritin $250 \mathrm{r} / \mathrm{kg}$ 笳注の成績 (第 9 図)

$250 \mathrm{r} / \mathrm{kg}$ の割に lferritin を注射すると腸管運動は 第 9 図の如く投与後 15 分間は何等変化子諗めないが, その後僅かながら tonus 扣よび振幅は増加し観察時間 120 分论はそのまま続いた。

b) Ferritin $500 \mathrm{r} / \mathrm{kg}$ 筋注の成績（第 10 図） 初期に変化を認めないが，15 分前後から僅から $つ$ tonus $の$ 上昇と振幅の堌加が起る。注射後 60〜70 分の振幅の堌大を山として再び減少して行らた。 Tonus の上昇度は $250 \mathrm{r} / \mathrm{kg}$ と500 r/kg とでは明かな 相違を䍿めないが，振幅は処理前のすのと較べて 500 $r / \mathrm{kg}$ の方がやはり大きい。静脈内投与の様な短時䦓 且つ著明な変化を喼めないのは吸収速度が綬慢なため と理解している。

5) Urethan 麻酥家鬼の腸管内作 ferritin を注入 した成續（第 11 図）

検体腸管内飞 ferritin $250 \mathrm{r} / \mathrm{kg} を 2 \mathrm{ml}$ の蒸溜水に 溶かし体温に温めたものを注入してその運動をみたの が第 11 図である。注入後 4 5 分で tonus が極く僅 か忍進するが，15 分前後で復元する。振幅は殆んど 変化がないこの実験で得られた晹管運動の变化は ferritin そのものの直接作用とするよりもむしろ内容 物の注入により生理的晹管連動が起ったものと考えた 方か妥当か子知れない。

6) Urethan 麻醮家鬼の晹管䈋膜化 ferritin を作 用させた場合の腸管運動（第 12 図，第 13 図）

検体腸管を ferritin 10 r/al 加 Ringer 液中に浮か ヘて運動を描写したのが第 12 図である。この腸管は 特に振幅が大きい例であったが，ferritin を作用させ たら5 分後より次第に tonus が減弱し, 明かた振幅 の抑制続いて振幅は恢復するが，その大きさはさしろ 無処理の時期のものよりも僅加増大の傾向にある。し かし就去 30 分で振幅も tonus \&正常状熊に移行 する。Tonus の回復は振幅のそれに較べて崌れる。更 飞 ferritin 濃度を増して $500 \mathrm{r} / \mathrm{dl}$ とすると同様な抑 制が起つて来るが，10 r/dl 江認めた㴍な自然回復が 起らず第 13 図の如く 25 分以上に亘つて抑制が続く。

この時期に新しい Ringer 腹上交換すると雪び運動が 現われて来るが，ferritin をこれに追加すると再び抑 制現象が起る(第 13 図)。

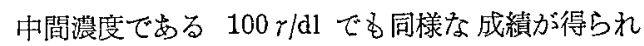

抑制が和こり，注㴪によって回復するのが認められ た。即ら低敬度の ferritin を桨膜より作用させると， 一時的の tonus の低下, 振幅の減弱が起るが, 濃度 が高くなると tonus の低下ょよび振幅の抑制効果は 長く続くことが示された。

7) Urethan 麻醉家息に塩化第二鉄を静注した实験 (第 14 図)

家兔々血清鉄飽和度以下の鉄を極めて徐々飞静注し てる腸管連動に影響老及ばさないが，極めて多量の鉄 を投与すれば中毒淀状を起して敏れる。 鉄として 500 $r / \mathrm{kg}$ 程度を徐々に投与しても多くの場合中毒症状を 垫めずに経過するが，この祭の腸管運動を描写したの が第 14 図で投与後 15 分迄は無影濞であるがその後振 幅の增加が諗められる。然し tonus の変化は殆えどな

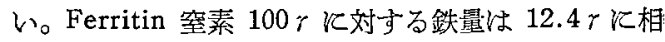
当するので，投与 ferritin 毁に相当する 鉄量では腸 管運動に影響を及ぼさないことが解る。

8) Urethan 林醉家鬼に馬血清 globulin 学静眽内 投与した実験（第 15 図）

Ferritin の䖵白部分は globulin に属するという。 ここで結晶馬血清 globulin を $3 \mathrm{mg}$ 静注した成績は 第 15 図であつて，殆えど変化を認め得ない。

以上 1 8 の実験結果から一定量以上の ferritin を 動静脈何れの経路をとつて投与しても urethan 麻醉 家躳腸管の tonus 空艺進し，振幅の增大を招き，筋 注でも程度の差こそあれ恝められた。腸管, 踏膜に直 接作用させるとさしろ抑制的に衙くことを認めた。

次に ferritin が申枢神経を介するすのか或忟局所的 に直接作用して起るるのが観る事は極めて與味があ る。然し晹管運動は極めて複雑でそう簡単に ferritin の作用機転を把握するのは容易でなからうが，腸管の 連動に対して解つた動きを営さ二三の薬冎を併用して この間の模様を探るのる価值なしとしない。この観点 に就て行つたものが以下の奏験である。

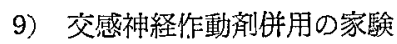

a) Adrenalin の単独使用成績（第 16 図）

Adrenalin $200 \mathrm{r} / \mathrm{kg}$ の割合 urethan 麻醉家鬼 に筋注した場合の晹管運動を描写した（第16図)。 Adrenalin 投与後腸管の tonus 恃急激仁低下し，振幅 運動す又減弱する。約 2 分間は耐者共殆えで消失した， ま亲経過するが次第に回復する。この際振幅 tonus 共 に正常以上に元進することはない。この adrenalin 作用は徉来の報告によく一致した。

b) Adrenalin $200 \mathrm{r} / \mathrm{kg}$ 筋注後 ferritin $250 \mathrm{r} / \mathrm{kg} \cdot \mathrm{c}$ 


$$
\text { (383) }-39-
$$

静脈内に投与した成續（第 17 図，第 18 図）

Adrenalin 筋注直後 ferritin $250 \mathrm{r} / \mathrm{kg}$ 静注する と, 第 17 図の様见 adrenalin の初期の効果即ち振幅 及び tonus の低減が全く見られずに ferritin による 腸管の振幅並びそ tonus の堌加の多が描写されて来 る。然し通常 $250 \mathrm{r} / \mathrm{kg}$ 投与で初期に起る早急な变化 殊汇 tonus の元進悓わ机ない。振幅の増大心 ferritin 単独の場合汇較ベて稍少い。Ferritin $250 \mathrm{r} / \mathrm{kg}$ 投与してとの效果が最大に現われた時期に adiena. lin $200 \mathrm{r} / \mathrm{kg}$ 投与すると第 18 図の様湖加 ferritin の作用を抑制した。これ等の成續から adrenalin ferritin 㤬抗作用があることが解る。

10）副交感神経作動剂併用の実験

a) Acetylcholine $の$ 単独使用成續 (第 19 図, 第 20 図, 第 21 図)

Urethan 麻醉家鬼泟 acetylcholine $10 \mathrm{mg} / \mathrm{kg}$ 筋注すると動物は症變を起し，整時で仮性 shock 症 状を招く。この状態は 5 10 分の後に回復するが晌相 当重篤な状態を残す。腸管注わ現われる変化は第 19 図 に示した通りで，薬凨の投与後直ちに tonus の元進が 現われ極めて不規則な曲線を描いて経過寸る。そこで acetylcholine $5 \mathrm{mg} / \mathrm{kg}$ の割合に減じると第 20 図 前半の曲線の通り $10 \mathrm{mg} / \mathrm{kg} の$ の投与成䋶から推した程 tonus 及び振幅の増大はなくその影響は僅少であっ た。

Acetylcholine $2.5 \mathrm{mg} / \mathrm{kg}$ 投与です第 21 図前半の 如く殆えど同様である。

b) Acetylcholine 投与後 ferritin 負荷した実験

i）予め投与する acetylcholine を $2.5 \mathrm{mg} / \mathrm{kg}$ として ferritin 投与量を $50 \mathrm{r} / \mathrm{kg}$ とすると，acetyl choline 飞よる本来の振幅の増大恃僅か沉認められた が， ferritin 追加で特に増加したとは考克られない (第 21 図)。

ii) Acetylcholine を増量して $5 \mathrm{mg} / \mathrm{kg}$ 投与し， 次で ferritinを $50 \mathrm{r} / \mathrm{kg}$ 負荷すると, 既述の通り ferritin $50 \mathrm{r} / \mathrm{kg}$ の静注で江腸管に何ら特別の変化を 認めなかつたが, 本例の如く予め acetylcholine $5 \mathrm{mg} / \mathrm{kg}$ 投与したるのは急激な tonus の上昇を伴う 萆明な振幅の增加が起った(第20図)。

この実験から acetylcholine と ferritin とはその 作用が同一方向である事が解り，且つferritin の作用 が acetylcholine の投与て堌強される事が示された。

c) Histamine 投与実験（第 22 図，第 23 図，第 24 図)
Histamine $50 \mathrm{r} / \mathrm{kg}$ の割合に筋注して， 50 60 分に亘り腸管運動を钼察したが，特に認める椂な変化 はなかった(第 22 図)。Histamine を62.5 r/kg V增 量すると，第 23 図の様汇投与後 7 分頃から振幅が多 少增大乙約 5 分間続く。更飞 $125 \mathrm{r} / \mathrm{kg}$ 《増量与る 之, 第 24 図の样に注射直後から 振幅が次第に大きく なるが，約 10 分後より tonus る增して来て約 15 分 間任亘り作用が続く。これ等の実験成續から histamine は麻醉家鬼晹管では $62.5 \mathrm{r} / \mathrm{kg}$ 以下では腸管運 動代著しい影響を及ぼさないのを識り，histamine は 極めて微量で効果があるうと予想したのと反した成績 であった。

ここで histamine の効果が余り 明瞭でない量 62.5 $r / \mathrm{kg}$ を投与し ferritin を 50 r/kg 静脈内投与すると

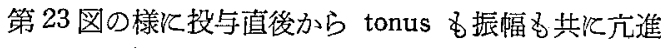
乙長時間に亘って続いている。この成績は ferritin $\mathbf{5 0}$ $r / \mathrm{kg}$ の静注では陽管渾動何等影響を及ぼさないの K，予め少量の histamine を投与して置くと，穴進 効果が㷦められるということを示するのである。

11）副交感神経作用抑制剂使用の実験

前後の実験目的と腹背の関係にある所謂植物神経遮 断剂を使用しこの実験を試みた。

a) Atropine 投与実験 (第 25 図)

Ferritin $250 \mathrm{r} / \mathrm{kg}$ 静注すると腸管運動は急激炕苋 進するが，その最高に達する時期化硫酸 atropineを $0.2 \mathrm{mg} / \mathrm{kg}$ 筋注すると強力な抑制が起って，12〜13 分以内に tonus，振幅共飞殆えぞ消失する。30 分経 過してから振幅が徐々K再現し正常に還る。

b) Papaverine 投与実跧（第 26 図）

Ferritin $250 \mathrm{r} / \mathrm{kg}$ を静注して腸管運動の六進した時 期飞 $4 \%$ papaverine $0.4 \mathrm{~m} l$ を皮下注射すると atropine の場合上同様投与後 3〜5 分で feritin よよる振 湢の急速なる減少と tonus の緩慢な減衰が起り，次 で晹管渾動が静止する。

これらの成續から atropine 及び papaverine は ferritin とよる腸管の振幅運動を㧕制し, tonus 低 下させる。然し振幅の念速な抑制化較べると tonus の 低下は緩やかであった。

c) Restamin 投与実験（第 27 図～第 30 図）

抗 histamine 剂である Restamin ( $\beta$-dimethyl aminoethyl benzhydrylether) と ferritin とを組合 せて実験した成績である。

Restamin $3 \mathrm{mg} / \mathrm{kg}$ 定予め投与し， 10 分後保 ferritin $250 \mathrm{r} / \mathrm{kg}$ 静注すると, ferritin による腸管運 
動ので進が起るが， Restamin とよつてその艺進効 果が特浪制されたと法考光られない(第 27 図)。

Restamin を更涪加して $6 \mathrm{mg} / \mathrm{kg}$ 爻予め投与し， 10 分後に ferritin を投与した実験では tonus の上 昇, 振幅の増大は注射後明か、起るが, 振幅の堌大は 対照 ferritinの振幅に較べれば僅か抑制されていると 考えられる。本例では tonus の正常化汇長時間かかつ ているのが目立つ(第28図)。

Ferritin $250 \mathrm{r} / \mathrm{kg}$ 静注で起った騰管運動が最も著 明となる 1〜3 分後に，Restamin を 3〜6 $\mathrm{mg}$ 筋注 したものが第 29，30図である。Ferritin $250 \mathrm{r} / \mathrm{kg}$ 単 独注射似よつて得られた從来の成績から推す之， Restamin の投与に上つて振幅の減弱が速かであるとは 言えるが，著明な効果があつたとは言い難い。この実 験です解る样汇 Restamin の作用は正常の晹管運動 そ対しては余り著効を譛めないが，何等かの原因で䒕 進している場合《注少なりとも抑制効果が認められ る。

\section{2）迷走神経切断実験}

Urethan 麻醉家鬼の迷走神経を横隔膜下にて切断 乙, 術後約 1 時間飞 ferritin $250 \mathrm{r} / \mathrm{kg}$ 静注乙腸管 運動を観察したのが第 31 図 (a)である。明か江急速 な tonus の尣進が起る。振幅の增大はこの例で恪余り 明瞭でない。

然し第 31 図 (b) の様に 振幅の増大が極めて明かで あるが，tonus の元進が緩慢な例とある。

迷走神経切断後の多くの例で (a) 例飞属するもの が多かった。然し何れにしてる, ferritin 投与によっ て振幅及び tonus 共元進が起ること柱否み難い。

\section{考按}

腸管運動を観察する為に家鬼を使用する事は海猽以 較べ，その運動が不安定で適当とは言い難いが，神経 血管等を損傷することなく，出来るだけ生理的状態で 他覚的尺度火より笑駼しようとする場合には小動物で は技術上の困難が伴うので，多少の犠牲を払つても家 鬼腸管を検体とする方法がよい。をこで一新法を提出 したが，この方法によると殊偒管の緊張度を適宣調 節して描写を行うと，個体により多少の相違があるに しても，60９0 分に亘り安定した腸䇺運動曲線を描 写出来る。実験中動静眽注射操作す可能であるから， この種の実験目的とは極めて好都合な方法と考える。 この実験方法を用いてさきに手代木が喼めた!ferritin 投与時の晹管運動の不安定性を直接倠認しょうと試 及成功した。即ち urethan 糜醉家乘仁一定量以上の馬 ferritin を動静脈何れの経路をとつて投与しても明か 飞腸管の tonus 及ざ振䋹は南進增大する。その效果 発現限界は静脈江於て ferritin $100 \mathrm{r} / \mathrm{kg}$, 勤脈江於て は ferritin $5 r / \mathrm{kg}$ で，凡そ 20 倍の美があつた。体 重の $1 / 13$ が血液量とすれば, 静注の場合は血中漰度 が $1.3 \mathrm{r} / \mathrm{ml}$ となり，動注では腸管局所に触れる. ferritin 港度柱血流の速さ，注射速度及び注射量より概 算乙て，凡先 $0.1 \mathrm{r} / \mathrm{ml}$ となり約 13 倍の相違がある。 然し静注時血流中で ferritin の破壤が起ると考党れ ぼ, 効果発現激度に差があっても不思議でい。

Mazur, Baez 等の ferritin K上る大の乏尿招来量 は末稍血管よりも直接局所分布敌脈汇注入した方が微 量で且著効のあることを譛めていることとよく類似し ている。

投与 ferritin 量き增加すれば，晹管運動は共に增 大するが，或る場合には㲗縮を招くことがある。動静 眽投与相互間の曲線上での相違性動注のうが tonus の 充進が振幅の增大㜔べて静注のものより，長時間続 く様である。筋肉注射では效果発現汕多量の fer ritin を必要とするが，恐らく ferritin の吸収が極め て徐々である為と考光られる。

䔉知の㥞记 ferritin ら成立つているが，この様な ferritin の效果が何れ の部分に負うすのであるうか，この点を決めるには鉄 micell を分離しなければならないがこれは不可能て ある。然し鉄 micell が何等かの働きするるの就ら ぼ，当然ion化したるのでなくてはならないから，效 果を招いた ferritin に相当した $\mathrm{FeCl}_{3}$ を使用してそ の作用を観察した所, 何等認める変化がなからた。最 近 Shorr 等》とよると ferritin はそこの分子の周围に 僅少の ion 化二価鉄を持ち, apoferritin 分子内 SH

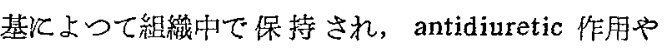
V.D.M. 作用はこの $\mathrm{Fe}^{++}$が主動であると言う。㣰つ て $\mathrm{FeCl}_{3}$ の实験成穓が陰生であつた事はもしこの現 象を劣てはめるなら理解出来る。しかし逆件鉄 micell の效巢次いては推定出来なくなる。一方 apoferritin は ferritin と同様火效果があること及び apoferritin が globulin 系炕属するといら事から血 清 globulin に就てその効果を観た所全く認め得なか つた等から ferritin の作用はむしう著者の実験成績 のみからすれば apoferritin 側にあると考觉たい。

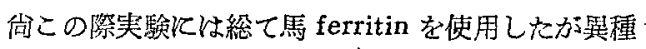

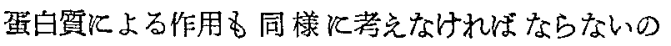
で，中島の法により家兄 ferritinを調製し使用すると 
僅かをの効果恃少る様であるが同栐の效果を喼めたの でこの点は否定出来た。

晹管の運動は腸管内圧の変化, 血液 $\mathrm{pH}$ の変動及び anoxia の有無等極めで椱雑な因子炕ら影響を受け るが，他方運動は植物神経により支配を受け，これに 筋读中の Auerbach の自動中枢があずからている。交 感神経の刺㦸で抑制され迷走神経の䒕奮で方進する事

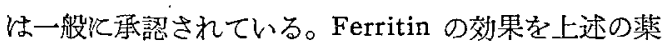
抄使用成緽から観ると，迷走神経を通して行われる様 飞推定されるが，迷走神経を横隔膜下で切断してる

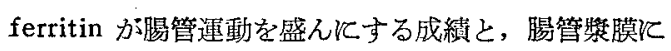
ferritin 触れさせると逆仰抑制効果が現われること と矛盾寸る。|Atropine は迷走神経の終板働くもの であるから，この楽剤で抑制される限り ferritin の作 用部分は終板より上位にあるべきである。迷走神経を 切断してる ferritin の元進効果孛認めることから切断 部より上位で支配を受けていることは考えられない。 従つて Auerbach 神経丵に直接作用することを除外 すれば，迷走神経終板部と切断部より末稍との間征 ferritin の侵襲点があるとしなければならない。また 血管壁には ganglion を中心とする反射弓の存在が考 えられているが，これがどの程度 ferritin の作用と関 係するか不明である。漿膜よりの作用効果の paradox 注如何に説明すればよいか，ferritin 加 Ringer 液の 洗涤除去で再び運動の抑制が除かれ再度作用させる事 により抑制が起ることからこの笑験成䋶には誤りがな い。

然し ferritin の作用澧度が経動脈的に投与した発動 濃度と殆んど等しいことから逆効果は考えられない が, 解剖学的飞腸管神経分布を観ると Aurerbach 神 経羟は一方粘膜に向つて網状火分布し, それが集中乙 て Flex. mesentericusに，他方はこれまた微細な網 状を呈して獎膜下分布するという。従つて自律神経 系の末端分布よりもより微細位がつているので，薬 物行対して鋭敏度が高いと推定される。従つて罯度が 同じでもその感受性が大きく，且つ注射の場合と異つ て長時間作用するので麻痺を招き，上述の如く抑制効 果が現われるものと解釉出来る。然しこの問題は更に 十二分検傠を要するものである。

\section{結論}

Ferritin の家兔晹管に及ぼす影響沉就て研究し, 次 の結果を得た。

1）先づ家鬼腸管運動描写法に就て比較㭘傠し, 新 てい非摘出晹管運動描写法を考案した。その特微は腸
管を可及的に正常状態保占得，且つ腸管の緊张度を 自由訊調節出来るのでその描写鋭敏度は高い。又実臨 中対照晹管内外上りの条件負加は勿論腸間膜分布血管

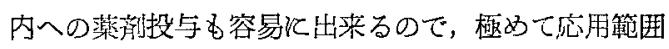
が広い方法である。

2) 本法によつて urethan 麻醮家医の正常晹管運 動を描写すると三型に分類出来るが，通常は論交中の a) 及びb) 型を示すものが压倒的多い。運動の強さ は個体によつて相違する。

3）馬 ferritin ferritin $N$ として pro kilo 50 r

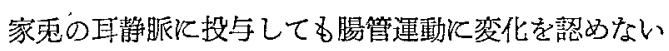
が，100r 飞なると腸管の tonus 法投与後急激江上昇 乙，振幅す增大する。然し 30 分前後で復旧する。 Ferritin N 1000 r投与では腸管は初期江一特的症縮 を起すが，直ちに回復し，次で tonus 及び振幅の著明 な元進を認める。且つ六進の持続時間は延長する。

4) Ferritin $5 r$ ferritin $N$ pro kilo の割合に 対照腸管分布動脈飞注入すると，tonus 及び振幅は 增大するが，短時間内正常復する。この際 tonus

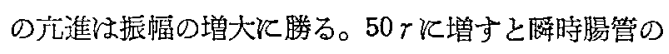
tonus 及び振幅山消失するが, その後急激な污進が起 り, tonus 证長時間任亘り六進状熊が続く。

5) 筋肉内に ferritin $250 r$ ferritin $\mathrm{N}$ pro kilo の割合飞注射しても著変を認めないが，500 r增加 すると腸管の tonus 及び振幅の增大が認められる。

6）腸管腔队に ferritinを注入しても変化がな い。

7) 晹管嶈膜加 5 ferritin を $10 r$ ferritin $\mathrm{N}$ pro kilo 以上作用させると腸管運動の抑制が起る。

8）対照実験の意味で塩化第二鉄を pro kilo $500 r$ 及び馬 globulin 液を静が汇静脈から投与してる腸 管運動特別の変化は起らない。

9） Ferritin の腸管運動に作用する機序を識るため 飞種々の葙剂を使用して実験した。先づ adrenalin は ferritin の作用之拮抗的働〉。

10） Ferritin の作用と acetylcholine とはその作 用が同一方向で，ferritin の作用が acetylcholine の 投与で増強される。

11） Histamine の作用が不明滕の量でも予め投与 してょくと ferritin の效果は增加する。

12) Atropine 及び papaverine は ferritin の效 果を抑制する。

13）Restamin 注著の使用量では ferritin の作 用に特に明かな影響を及ぼさなからた。Ferritin 投与 
$-42-(386)$

で腸管運化が元進した状態では多少抑制的に作用する のを惩めた。

14）迷走神経横隔膜下切断家鬼の晹管運動は ferritin によつて増加が起る。

$$
\text { 文献 }
$$

1)手代木正：生化学，29，177(1957)；29，285 (1957); 29, 480 (1957)

2) Mazur, A., Shorr, E. : J. Biol. Chem., 176, 771 (1948)
3) Baez, S., et al. : Am. J. Physiol., 169, 123 (1952)

4) Noble, R., et al. : Quart. J. Exper. Physiol., 31, 201 (1942)

5) 村田耕治：日本外科学会雜誌，57，1853(1957)

6) 帠田敏夫：生物化学最近の進歩第 2 咕（技報堂 1956)

7) 中島信治：生化学, 28, 378 (1956)

8) Mazur, A., Baez, S., and Shorr, E. : J. Biol Chem., 213, 147 (1955) 


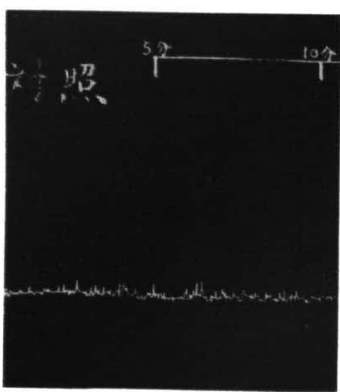

a)

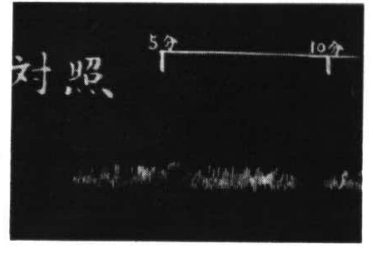

b)

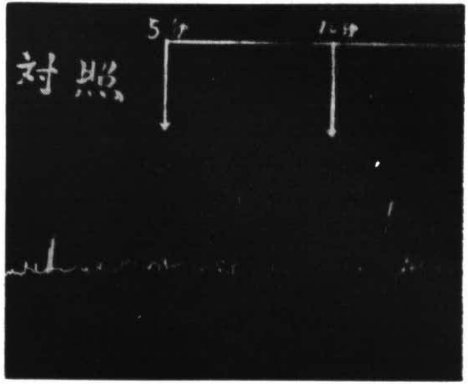

c)

第 2 図 Urethan 麻酔家克の腸管運動

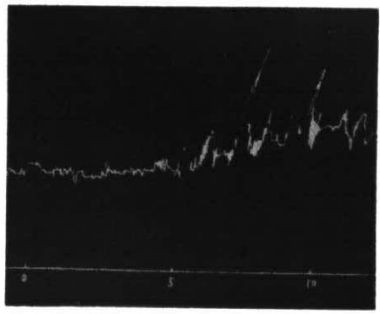

第 3 図 Vagostigmine 注射 $(0.1 \mathrm{mg} / \mathrm{kg}$ 皮下)

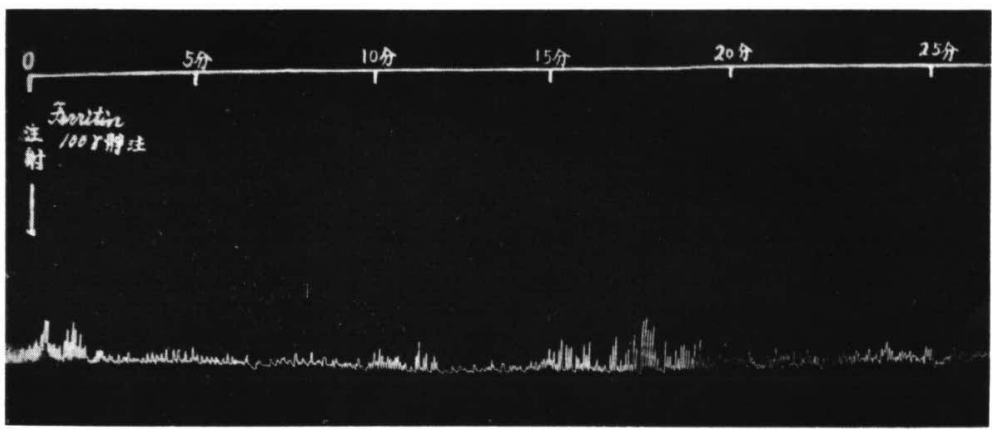

第 4 図 馬 ferritin 50 r $/ \mathbf{k g}$ 耳静脈静注

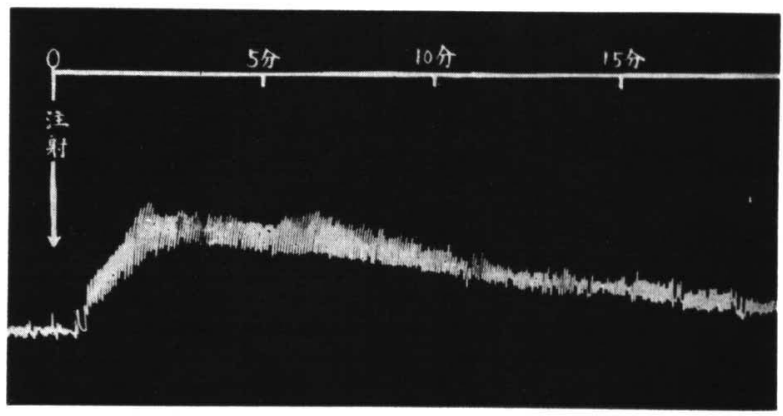

第 5 図 馬 ferritin 100 r $/ \mathbf{k g}$ 耳静脈静注 
$-44-(388)$

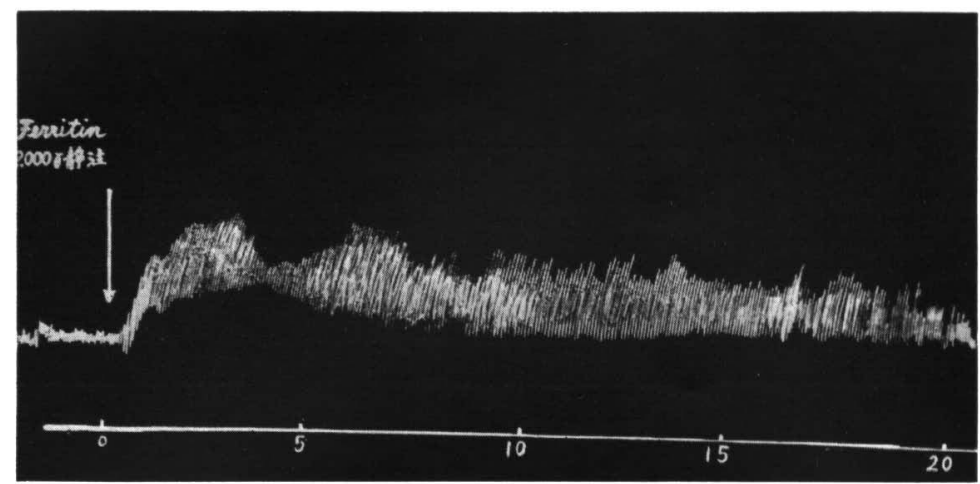

第 6 図 馬 ferritin $1000 \mathrm{r} / \mathrm{kg}$ 耳静脈静注

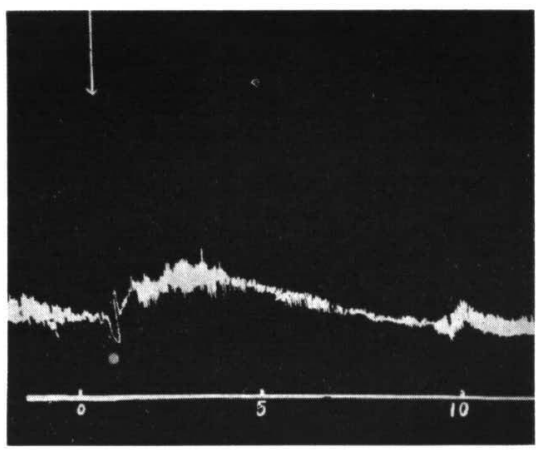

第 7 図 馬 ferritin 5 r $/ \mathrm{kg}$ 腸間膜動脈内注入

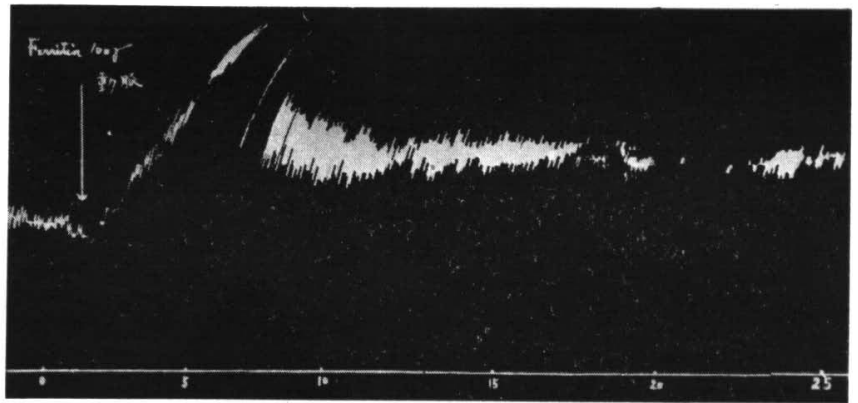

第 8 図 馬 ferritin $50 \mathrm{r} / \mathrm{kg}$ 腸間膜動脈内注入

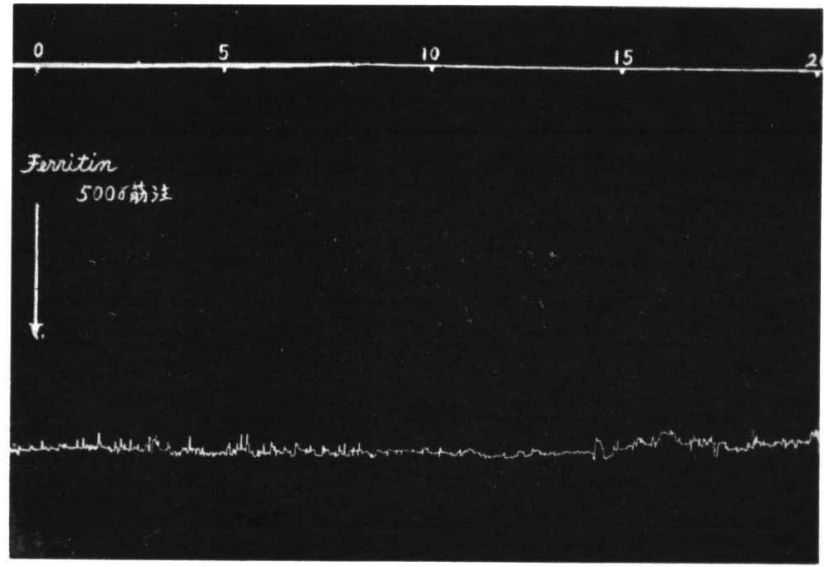

第 9 図 馬 ferritin $250 \mathrm{r} / \mathrm{kg}$ 筋注 
( 389$)-45$

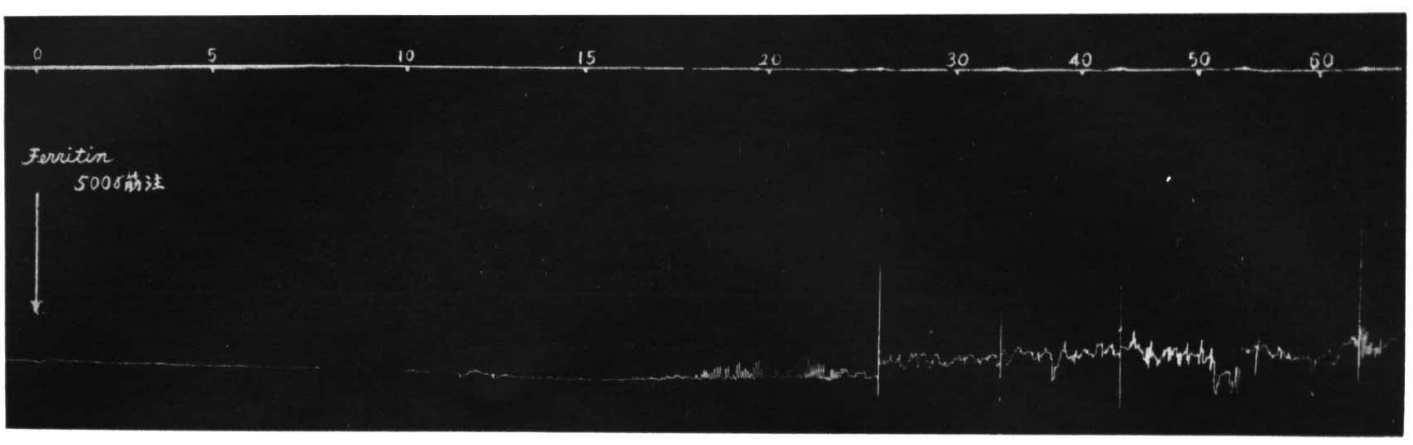

第 10 図 馬 ferritin $500 \mathrm{r} / \mathbf{k g}$ 筋注

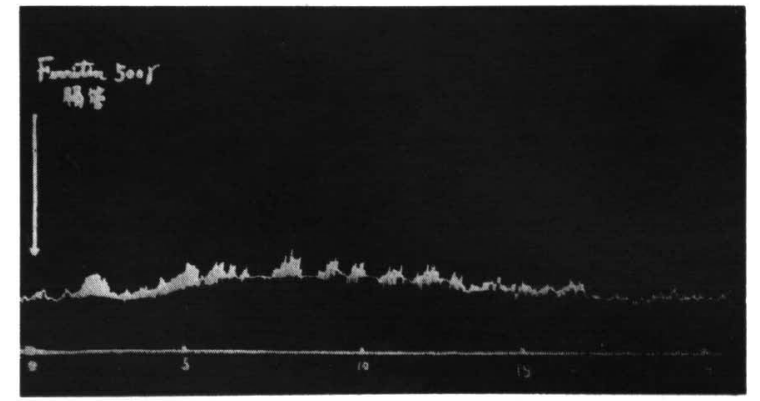

第 11 図 馬 ferritin $250 r / \mathbf{k g}$ 腸管内注入

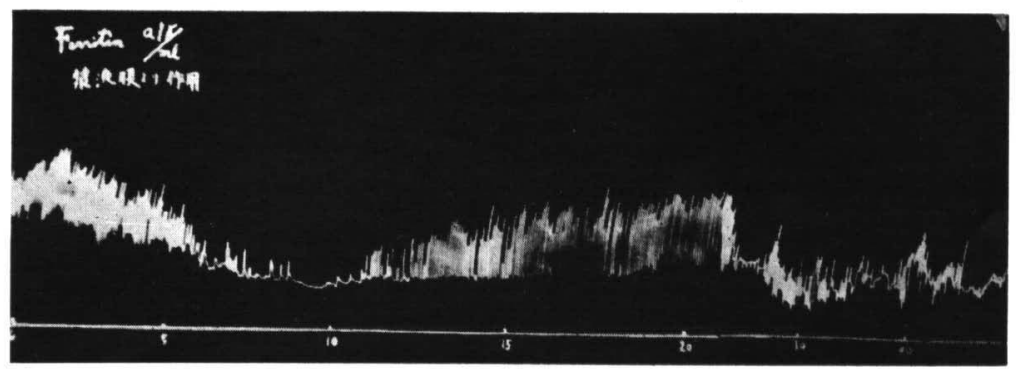

第 12 図 馬 ferritin $10 \mathrm{r} / \mathrm{dl}$ 漿膜より作用

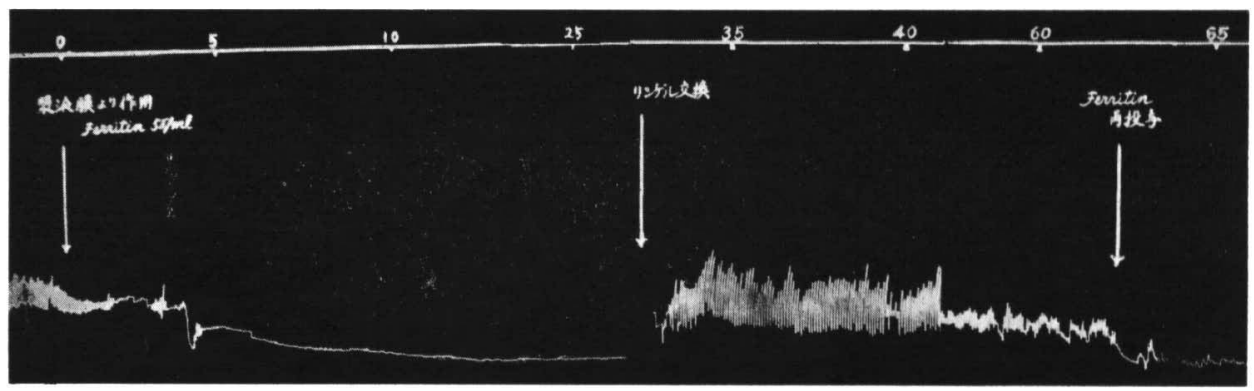

第 13 図 馬 ferritin $500 \mathrm{r} / \mathrm{dl}$ 漿膜より作用 
$-46-(390)$

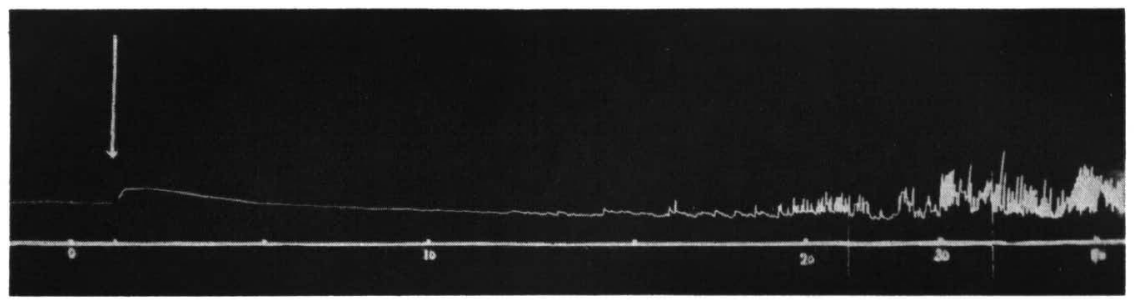

第 14 図塩化第二鉄 $500 \mathrm{r} / \mathrm{kg}$ 静注

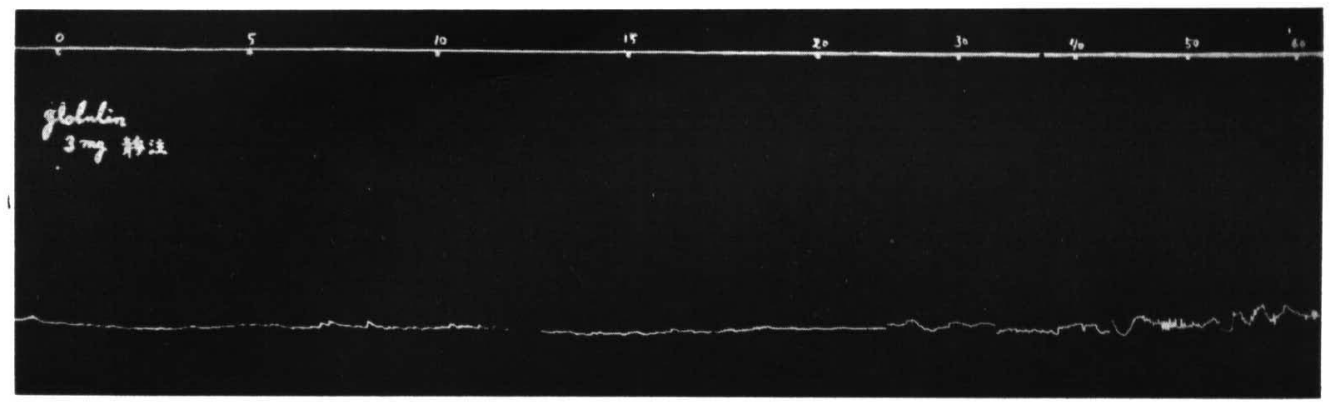

第 15 図 馬血清 globulin $3 \mathrm{mg}$ 静注

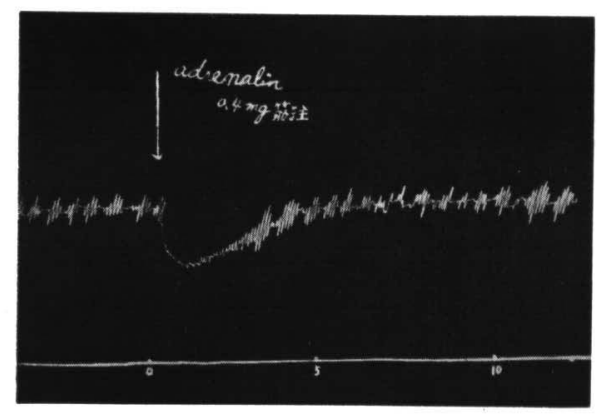

第 16 四 塭化 adrenalin $200^{*} \gamma / \mathrm{kg}$ 筋注

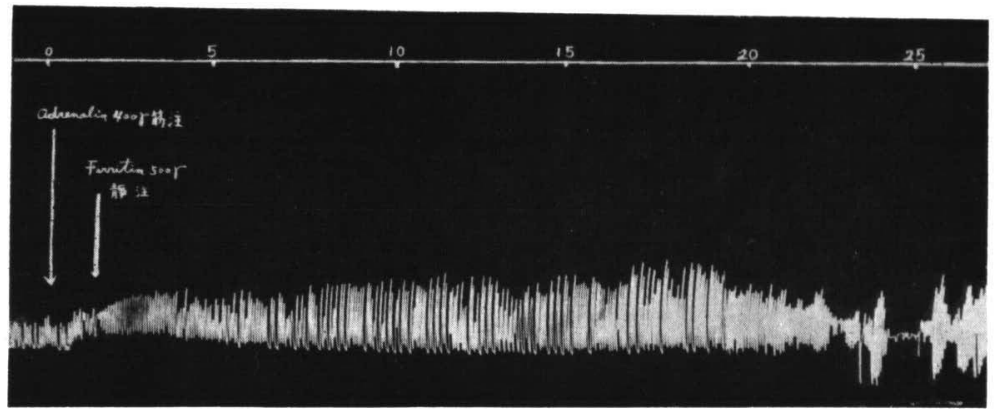

第 17 図 塩化 adrenalin $200 r / \mathrm{k}$ 筋注後 ferritin $250 r / \mathrm{kg}$ 静注 


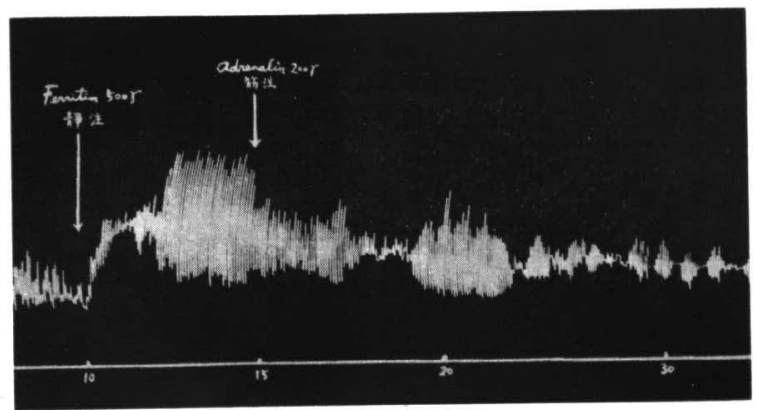

第 18 図 Ferritin $250 r / \mathrm{kg}$ 静注後塩化 adrenalin $200 \mathrm{r} / \mathrm{kg}$ 筋注

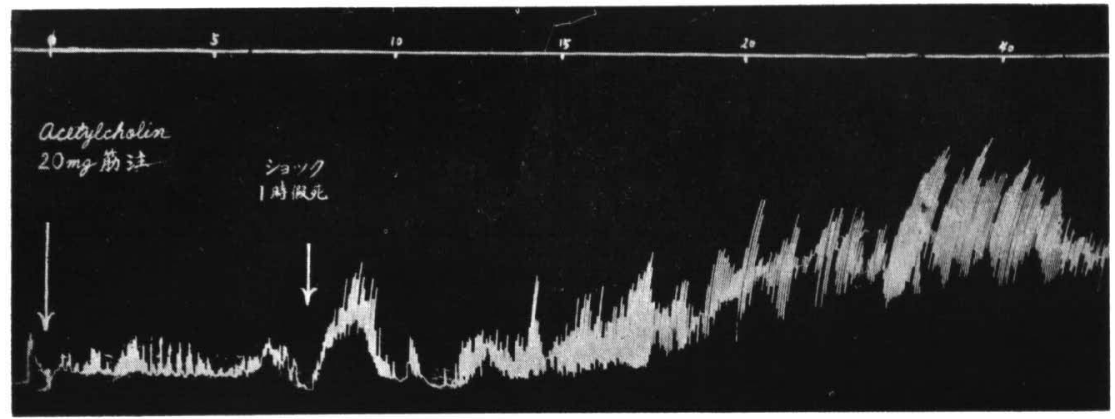

第 19 図 Acetylcholine $10 \mathrm{mg} / \mathrm{kg}$ 筋注

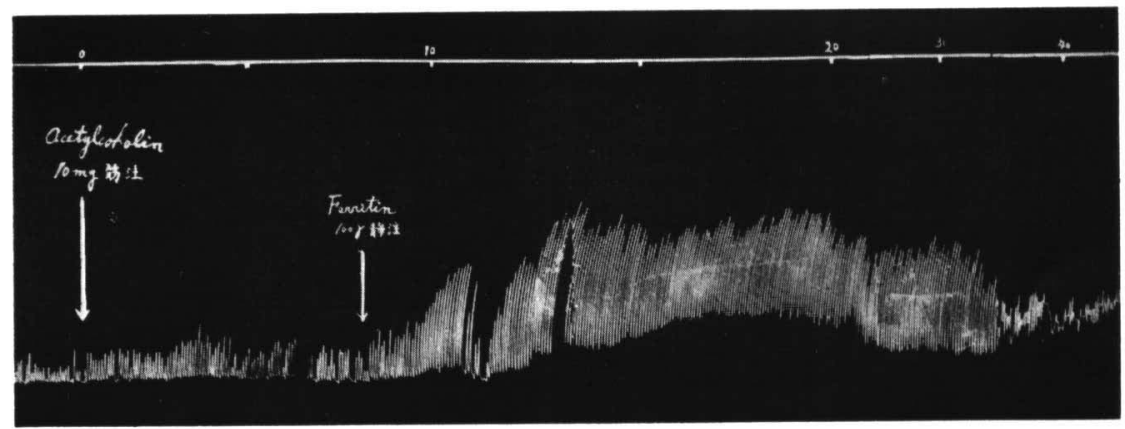

第 20 図 Acetylcholine $5 \mathrm{mg} / \mathrm{kg}$ 筋注後 ferritin $50 \mathrm{r} / \mathrm{kg}$ 静注

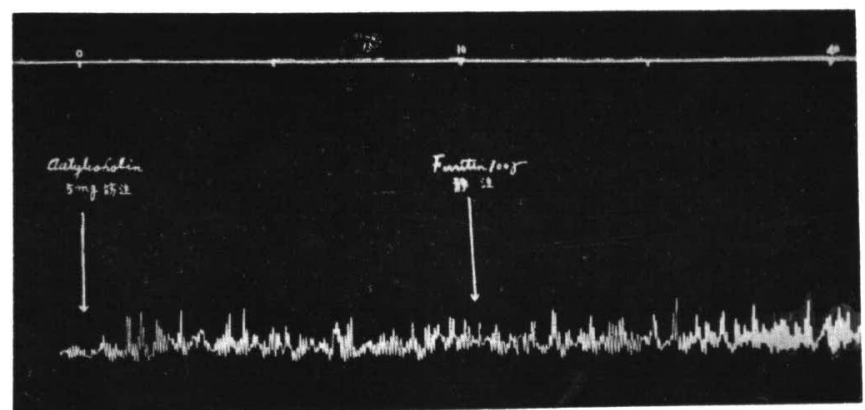

第 21 Acetylcholine $2.5 \mathrm{mg} / \mathrm{kg}$ 筋注後 ferritin $50 \mathrm{r} / \mathrm{kg}$ 静注 
$-48-(392)$

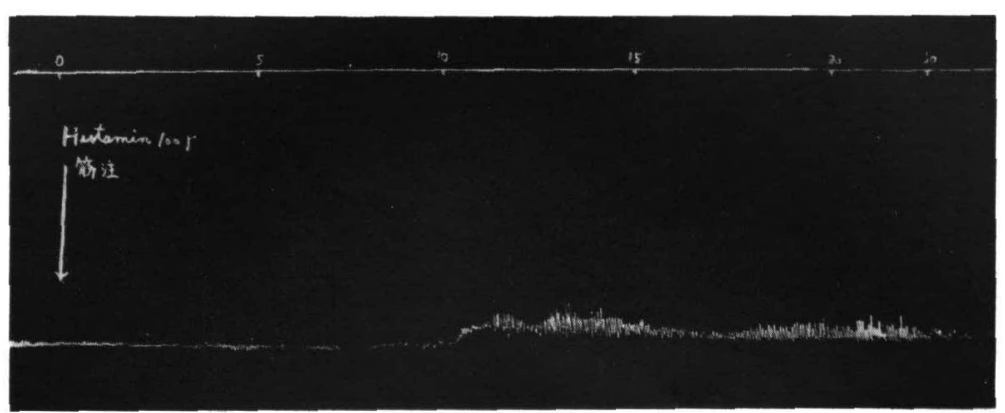

第 22 図 Histamine $50 r / \mathrm{kg}$ 筋注:

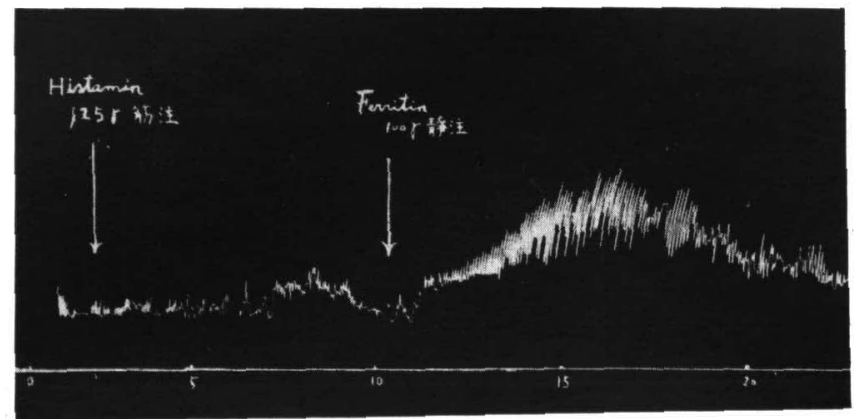

第 23 図 Histamine $62.5 \mathrm{r} / \mathrm{kg}$ 筋注後 ferritin $50 \mathrm{r} / \mathrm{kg}$ 静注:

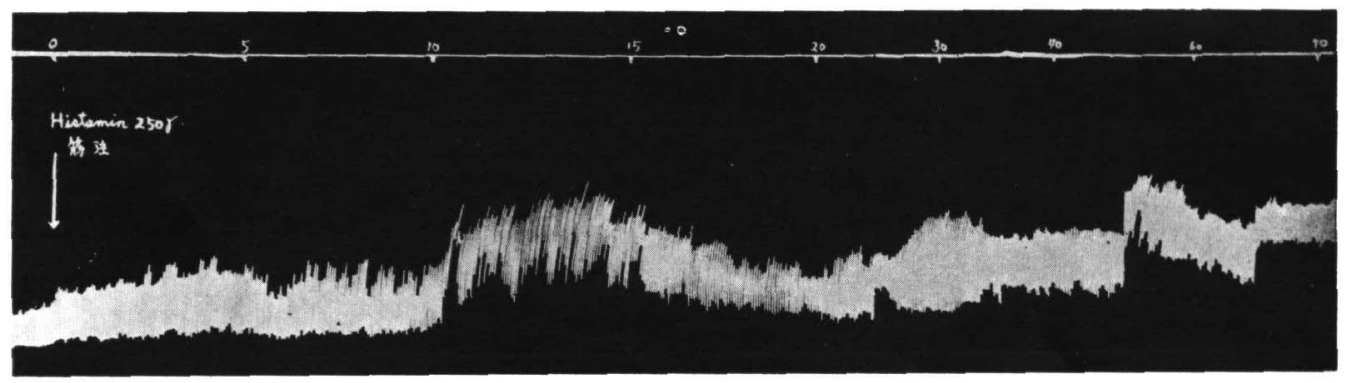

第 24 図 Histamine $125 \gamma / \mathrm{kg}$ 筋注

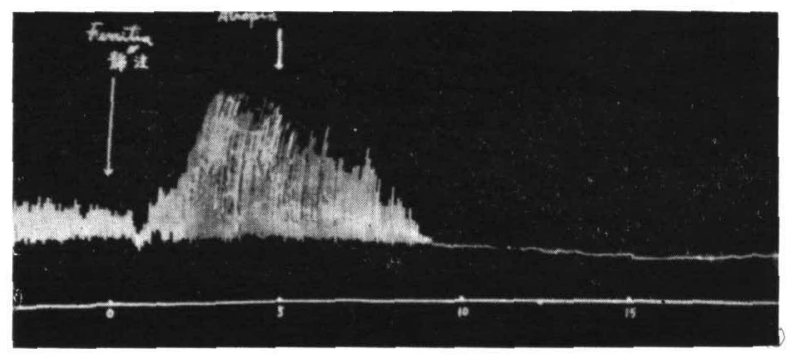

第 25 図 Ferritin $250 \mathrm{r} / \mathrm{kg}$ 静注後硫酸 atropine $0.2 \mathrm{mg} / \mathrm{kg}$ 筋注 


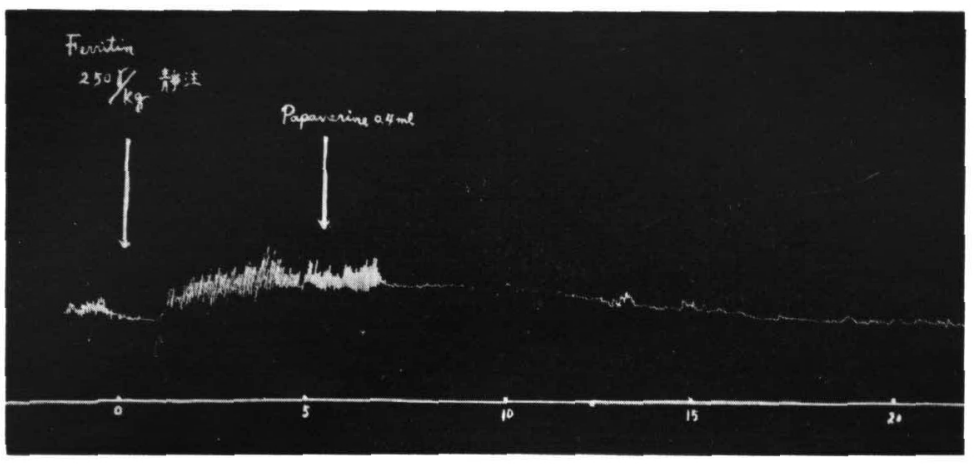

第 26 図 Furritin $250 \mathrm{r} / \mathrm{kg}$ 静注後 $4 \%$ papaverine $0.4 \mathrm{ml}$ 筋注

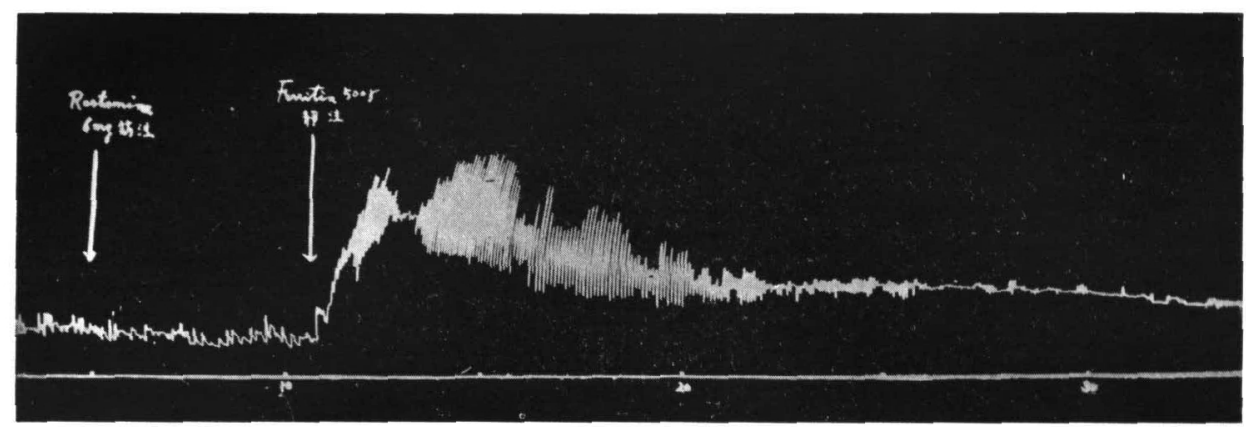

第 27 図 Restamin $3 \mathrm{mg} / \mathrm{kg}$ 筋注後 ferritin $250 \mathrm{r} / \mathrm{kg}$ 静注

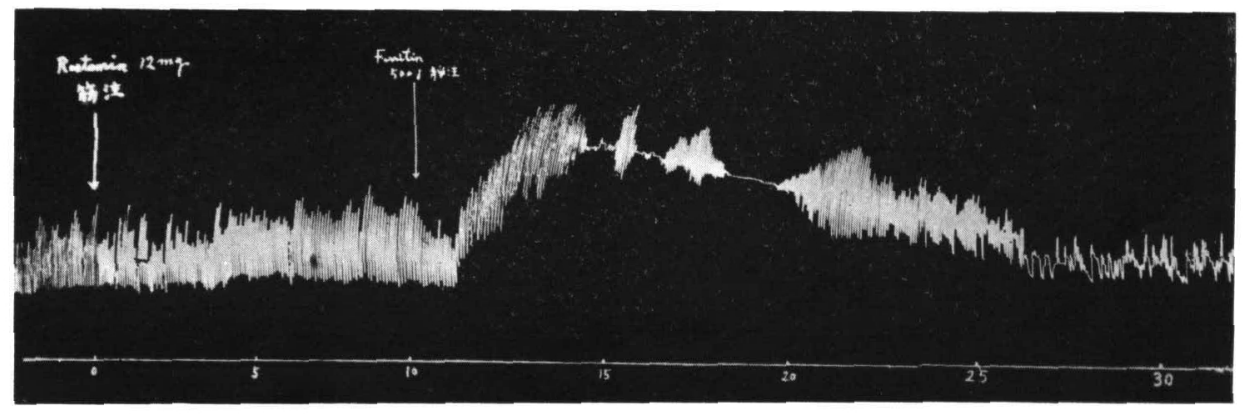

第 28 図 Restamin $6 \mathrm{mg} / \mathrm{kg}$ 筋注後 ferritin $250 \mathrm{r} / \mathrm{kg}$ 静注:

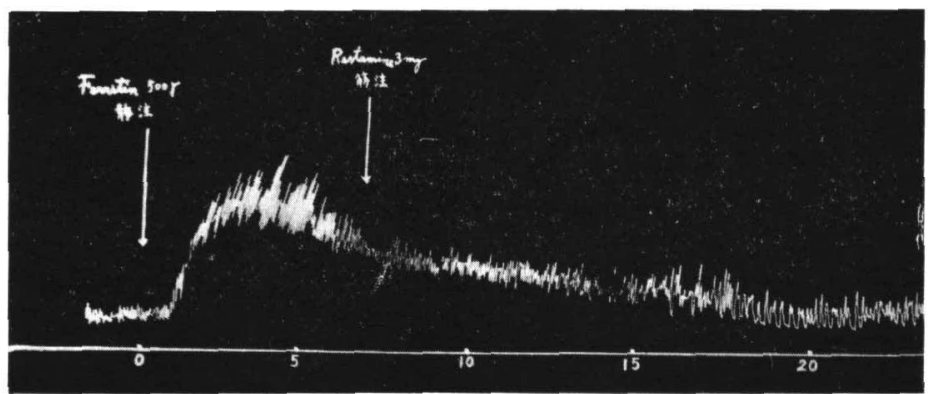

第 29 図 Ferritin $250 \mathrm{r} / \mathrm{kg}$ 静注後 Restamin $1.5 \mathrm{mg} / \mathrm{kg}$ 筋注 


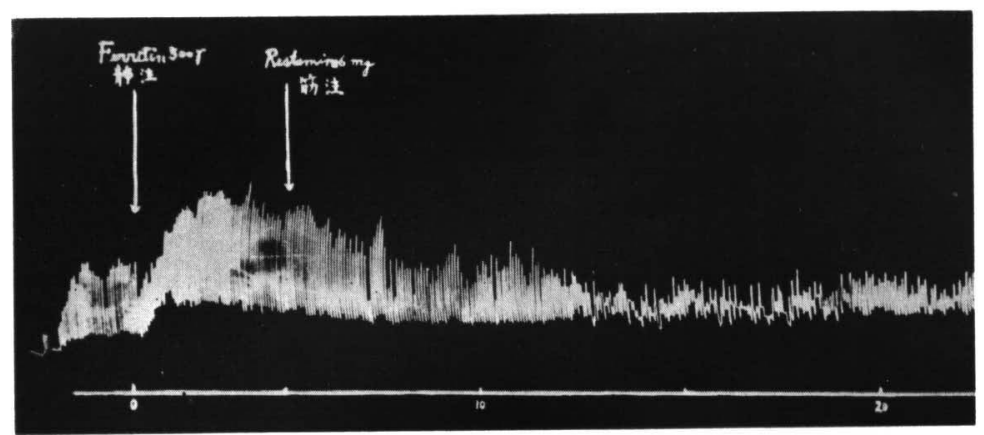

第 30 図 Eerritin $250 \mathrm{r} / \mathbf{k g}$ 静注後 Restamin $3 \mathrm{mg} / \mathbf{k g}$ 筋注

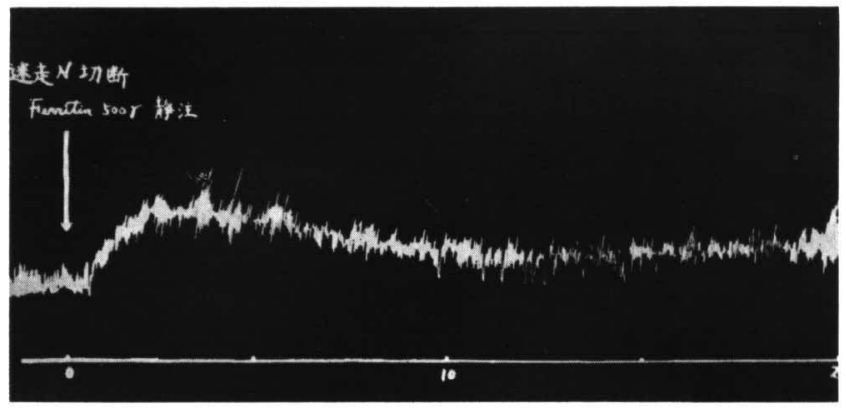

第 31 図（a) 迷走神経切断家鬼飞 ferritin $250 \mathrm{r} / \mathbf{k g}$ 静注

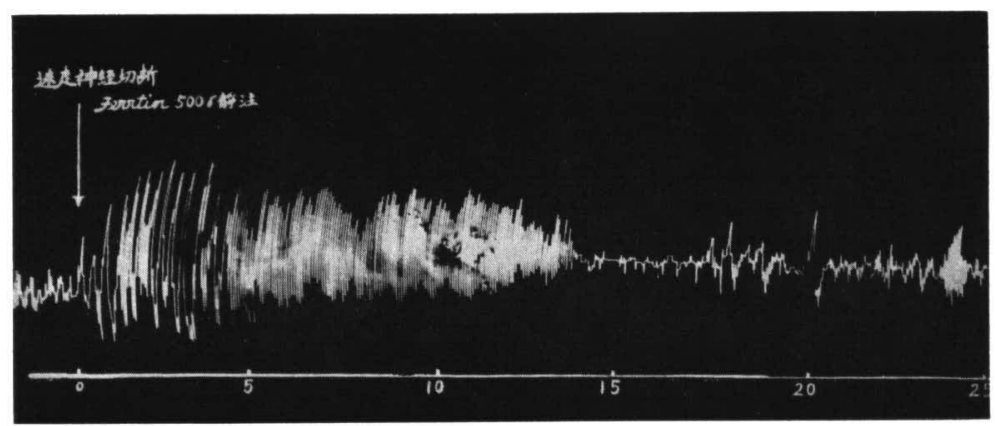

第 31 図（b）迷走神経切断家鬼飞 ferritin $250 r / \mathbf{k g}$ 静注 